\title{
"IEEE Transactions on Forensics and Information Security" jurnalının bibliometrik analizi (2006-2017-ci illər üzrə)
}

\author{
Nərmin Adigözəlova \\ AMEA İnformasiya Texnologiyaları İnstitutu, Bak1, Azərbaycan \\ narmin66@gmail.com
}

\begin{abstract}
Xülasə - Tezisdə Web of Science (WoS) bazasında indeksləşən "IEEE Transactions on Information Forensics and Security" (IEEE TIFS) jurnalında 2006-2017-ci illər ərzində çap olunmuş məqalələrin bibliometrik analizi aparılmışdır. Analiz məqalə və istinadların illər, müəlliflər, təşkilat və ölkələr üzrə paylanması istiqamətində aparılmışdır.
\end{abstract}

Açar sözlor- WoS, impakt faktor, istinad, bibliometriya, bibliometrik analiz.

\section{GIRIŞ}

Bibliometriya kitabların, məqalələrin və digər nəşrlərin statistik analizi olub, tədqiqatçının, məqalələr toplusunun, tədqiqat istiqamətinin və ya institutun fəaliyyətini ölçən elmi istiqamətdir [1]. Başqa sözlə desək, bibliometriya mətn və informasiyanın ölçülməsi üçün istifadə olunan metodlar çoxluğudur. Bu termin ilk dəfə 1969-cu ildə Pritchard tərəfindən işlənilmiş, riyazi və statistik metodları tətbiq etməklə kitabların, dövri nəşrlərin və digər çap məhsullarının qiymətləndirilməsi üçün istifadə olunur. Bura istinad, açar sözlər, nəşriyyatın adı, müəllif və s. kimi xüsusi dəyişənlərlə xarakterizə olunan nəşrlərin təhlili daxildir [2].

Bibliometriya mövzu, müəllif, istinad və s. kimi göstəricilərə əsaslanan və elmi sahələrə tətbiq olunan kəmiyyət yanaşmalarıdır. Bibliometriya vasitəsilə ilə tədqiqatçı bibliometrik qiymətləndirmə metodlarından istifadə edərək tək bir müəllifin deyil, iki və daha artıq müəllifin fəaliyyətini, tədqiqat işini və ya əməkdaşlıq əlaqələrini müəyyən edə bilər [3]. Bibliometriya alimlərin məhsuldarlığına statistik üsulları tətbiq edərək elmi inkişafi ölçür.

Bibliometriya multidissiplinar elm sahəsidir. Burada analizi həyata keçirmək üçün statistik üsullardan, sosioloqların hazırladiqları icmal və hesabatlardan, elektron cədvəllər, verilənlər bazaları və statistik proqramlar vasitəsilə verilənlərin emalı üçün kompüter elmlərindən istifadə olunur. Bütün bu imkanlar elmin istənilən sahəsində tədqiqatçıların işinin analiz olunmasına imkan verir. Tədqiqat sahəsinin məhsuldarlığı həmin istiqamətdəki nəşrlərin sayı ilə ölçülür [1].

Son illər informasiya təhlükəsizliyi məsələləri diqqət mərkəzindədir. Belə ki, texnologiyanın daha çox istifadəsi intensiv məlumatların toplanması və həmin məlumatların gizliliyi və təhlükəsizliyi ilə bağlı etik məsələlərin meydana gəlməsinə səbəb olmuşdur. İnformasiya təhlükəsizliyi milli İKT planlarının, e-dövlət, e-ticarət, e-tibb, o cümlədən e-təhsil fəaliyyət istiqamətlərinin hazırlanıb həyata keçirilməsində mühüm rol oynayır.

Yuxarıda qeyd olunanlarla yanaşı son dövrlər informasiya təhlükəsizliyi bir istiqamət olaraq akademik mühitdə olan insanların, tədqiqatçıların diqqətini cəlb edən istiqamətlərdən biri hesab olunur. Bu sahədə çoxlu elmi əsərlərin, jurnalların çap olunması tədqiqatçılara bu istiqamətdə bibliometrik analizlərin aparılmasına imkan yaratmışdır $[4,5]$.

Hər hansı sahə analiz olunarkən bu istiqamətdə çap olunan kitablar, məqalələr, tezislər, jurnallar və s. analiz olunur. WoS bazasında "security" sözü üzrə jurnalları axtarış etdikdə 22 adda jurnalın olduğu aşkarlanmışdır. Tezisdə bu istiqamətdə ən yüksək Impakt Faktor (IF) göstəricisinə malik IEEE TIFS jurnalı götürülmüş və jurnalın 2006-2017-ci illər ərzində çap olunmuş buraxılışları analiz olunmuşdur [6].

IEEE TIFS jurnalı informasiya ekspertizası, informasiya təhlükəsizliyi, biometriya, o cümlədən bu cür xüsusiyyətləri birləşdirən nəzarət sistemləri və sistem tətbiqləri ilə əlaqəli elm, texnologiya və proqram sahələrini əhatə edir.

Tezisdə IEEE TIFS jurnalında 2006-2017-ci illərdə çap olunan məqalələr və istinadlar üzrə analiz aparılmışdır.

Məqalələr üzrə aşağıdakı göstəricilər analiz edilmişdir:

- məqalələrin illər üzrə paylanması;

- məqalələrin tipə görə təsnifat1;

- müəlliflər üzrə analiz;

- müəlliflərin əməkdaşlıq dərəcəsinin müəyyən edilməsi;

- $\quad$ on məhsuldar müəllifin seçilməsi;

- məqalələrin təşkilatlar üzrə paylanması;

- məqalələrin ölkələr üzrə paylanması;

İstinadlar üzrə isə aşağıdakı göstəricilər analiz edilmişdir:

- istinadların illər üzrə paylanması; illər üzrə istinadın orta sayı; 


\section{“Informasiya tohlükosizliyinin aktual multidissiplinar elmi-praktiki problemlori” IV respublika konfransı, 14 dekabr 2018-ci il}

- istinad olunan sənədin növünün və sayının müəyyən olunmas1.

\section{BİBLIOMETRİK TӘDQİQATLAR SAHӘSINDD BEYNOLXALQ TӘCRÜBӘ}

Son illər bibliometrik tədqiqatlar sahəsində çoxlu araşdırmaları aparılır. Tezisdə bu istiqamətdə aparılmış bəzi araşdırmalara baxılmış və bir sıra nümunələr göstərilmişdir.

Dhiman "Ethnobotany Journal" adlı jurnalda 1989-1998-ci illər ərzində çap olunan məqalələri illər, ölkələr, təşkilatlar, istinadlar və məqalənin həcminə görə analiz etmişdir [7]. Patra və başqaları jurnal və müəllifllərin artımını analiz etmişlər [8]. Neff və Corley 1970-2005-ci illəri əhatə edən ekoloji sahələrdə mövcud yanaşmaları və mövzuları təyin etmək üçün əlaqəli sözlərin bibliometrik analizini araşdırmışlar [9]. Thanuskod sosial elmlər sahəsində aparılan araşdırmaların nəticələri haqqında analiz aparmışdır. Analiz əsasən istinad olunan jurnalları, istinad olunan sənədin növünü, hər məqaləyə düşən orta istinad sayını və s. əhatə etmişdir [10].

Bornman və Mutz XVII əsrin ortalarından 2012-ci ilədək çap olunan və istinad olunan ədəbiyyatları analiz etmişlər. Onlar elmin inkişaf səviyyəsini həmin müddətdən əvvəlki dövr ilə müqayisə edərək elmin inkişafinı 3 dövrə bölüblər:

1) XVIII əsrin ortalarına kimi $1 \%$ artım,

2) dünya müharibələri arasındakı müddətdə 2-3\%,

3) 2012-ci ilə qədər 8-9\% artım müşahidə olunur [11].

Abdi və başqaları "Information Processing \& Management" adlı jurnalında 1980-2015-ci illər ərzində çap olunmuş məqalələri müəlliflər, istinadlar, ölkələr, təşkilatlar və $\mathrm{s}$. göstəricilərə əsasən analiz etmişlər [12].

Jurnalların qiymətləndirilməsi üçün bəzi alimlər tərəfindən WoS və Scopus bazalarına əsaslanan müxtəlif göstəricilər təklif olunmuşdur. WoS və Scopus bazasından istifadə edərək nəşrlərin, müəlliflərin, açar sözlərin jurnalın sahələri üzrə təsnifat edilməsi, həmçinin müxtəlif göstəricilər arasında korrelyasiyanın aparılması mümkündür.

\section{BİBLİOMETRİK ANALIZİN NӘTİCəLӘRİ}

Qeyd olunduğu kimi tədqiqat işində WoS bazasında indeksləşən IEEE TIFS adlı jurnal analiz olunmuşdur. Jurnalı analiz etmək üçün WoS bazasında "Publication name" bölməsinə IEEE TIFS jurnalının adı daxil edilir. Axtarış nəticəsində 2006-2017-ci illər ərzində jurnalda 1639 sayda məqalənin nəşr olunduğu aşkarlanmışdır.

IEEE TIFS jurnalının 11 il ərzində IF göstəricisi şəkil 1-də göstərilmişdir. Şəkil 1-dən göründüyü kimi jurnalın IF göstəricisi ən aşağ 12007 -ci ildə (1.089), ən yüksək isə 2017-ci ildə (5.824) olmuşdur. 2010 və 2011-ci illərdə jurnalın IF göstəricisində nisbətən azalma müşahidə olunsa da, digər illərdə bu göstərici artmaqda davam etmişdir.

Tədqiqat işində analiz 2 istiqamətdə (məqalələr və istinadlar) aparılmışdır.

\section{Məqalə üzrə analiz:}

\section{A) Maqalalarin illar üzrə paylanması}

2006-2017-ci illər ərzində IEEE TIFS jurnalında 1639 sayda məqalə çap olunmuşdur. $\mathrm{Bu}$, o deməkdir ki, orta hesabla bu jurnalda il ərzində 136 məqalə çap olunmuşdur. Məqalələrin illər üzrə paylanması say və faiz nisbəti ilə cədvəl 1-də göstərilmişdir.

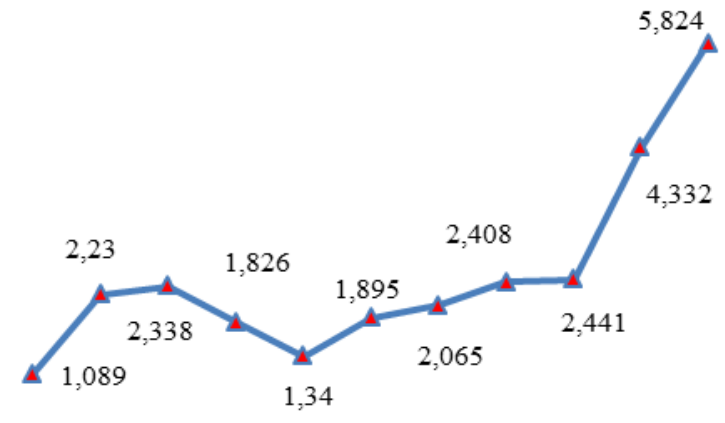

20072008200920102011201220132014201520162017

Şəkil 1. "IEEE TIFS” jurnalının IF göstəricisi

Cədvəl 1-dən göründüyü kimi ən az məqalə sayı 2006-c1 ildə (46 məqalə, 2,81\%), ən çox isə 2017-ci ildə (223 məqalə, $13,61 \%$ ) çap olunmuşdur.

CəDVəL 1. MəQALəLəRIN ILLӘR ÜZRə PAYLANMASI

\begin{tabular}{|c|c|c|c|}
\hline İ & $\begin{array}{c}\text { Jurnalın } \\
\text { nömrəsi }\end{array}$ & Məqalə sayı & \% \\
\hline $\mathbf{2 0 0 6}$ & $1(1-4)$ & 46 & 2,81 \\
\hline $\mathbf{2 0 0 7}$ & $2(1-4)$ & 70 & 4,27 \\
\hline $\mathbf{2 0 0 8}$ & $3(1-4)$ & 70 & 4,27 \\
\hline $\mathbf{2 0 0 9}$ & $4(1-4)$ & 83 & 5,06 \\
\hline $\mathbf{2 0 1 0}$ & $5(1-4)$ & 85 & 5,19 \\
\hline $\mathbf{2 0 1 1}$ & $6(1-4)$ & 121 & 7,38 \\
\hline $\mathbf{2 0 1 2}$ & $7(1-6)$ & 160 & 9,76 \\
\hline $\mathbf{2 0 1 3}$ & $8(1-12)$ & 178 & 10,86 \\
\hline $\mathbf{2 0 1 4}$ & $9(1-12)$ & 182 & 11,10 \\
\hline $\mathbf{2 0 1 5}$ & $10(1-12)$ & 205 & 12,51 \\
\hline $\mathbf{2 0 1 6}$ & $11(1-12)$ & 216 & 13,18 \\
\hline $\mathbf{2 0 1 7}$ & $12(1-12)$ & 223 & 13,61 \\
\hline Cəmi & & $\mathbf{1 6 3 9}$ & $\mathbf{1 0 0}$ \\
\hline
\end{tabular}

B) Maqalalarin tipa göra təsnifatı

Cədvəl 2-də jurnalın 2006-2017-ci illərdə çap olunan məqalələrin sənədin növə görə təsnifatı göstərilmişdir və ən çox məqalələrin üstünlük təşkil etdiyi görünür. Burada 15 məqalə konfrans materialı kimi daxil olunmuşdur. Buna səbəb həmin məqalələrin əvvəlki illər konfrans materialı olaraq çap olunub, daha sonradan genişləndirilib məqalə şəklində çap olunmasidir.

CəDVəL 2. MəQALəLəRIN NÖVə GÖRə TəSNIFATI

\begin{tabular}{|l|c|c|}
\hline \multicolumn{1}{|c|}{ Sənədin növü } & Say & \% \\
\hline Məqalə (Paper) & 1606 & 97.987 \\
\hline $\begin{array}{l}\text { Ön söz } \\
\text { (Editorial material) }\end{array}$ & 21 & 1.281 \\
\hline Tezis & 15 & 0.915 \\
\hline
\end{tabular}




\section{“Informasiya tohlükosizliyinin aktual multidissiplinar elmi-praktiki problemlori” IV respublika konfransl, 14 dekabr 2018-ci il}

\begin{tabular}{|l|c|c|}
\hline (Proceedings paper) & & \\
\hline $\begin{array}{l}\text { Redaktə olunmuş } \\
\text { (Correction) }\end{array}$ & 9 & 0.549 \\
\hline Məktub (Letter) & 2 & 0.122 \\
\hline İcmal (Review) & 1 & 0.061 \\
\hline
\end{tabular}

C) Müalliflar üzrə analiz

2006-2017-ci illər ərzində çap olunan məqalələri müəlliflər üzrə təsnifat etdikdə, yəni həmmüəlliflər üzrə qruplaşdırdıqda 1639 məqalədən 70-i təkmüəllifli, 404-ü ikimüəllifli, 470-i üçmüəllifli, 695-i isə 3-dən çox müəllifli olduğu aşkarlanmışdır. Cədvəl 3-dən göründüyü kimi 2006-2017-ci illər ərzində çap olunan məqalələrdə 3-dən çox müəllifli məqalələr üstünlük təşkil edir.

CəDVӘL 3. MəQALӘLӘRIN MÜəLLIFLӘR ÜZRӘ ANALIZI

\begin{tabular}{|c|c|c|c|}
\hline İl & Təkmüəllifli & Íkimüəllifli & Üçmüəllifli \\
\hline $\mathbf{2 0 0 6}$ & 3 & 18 & 15 \\
\hline $\mathbf{2 0 0 7}$ & 4 & 31 & 23 \\
\hline $\mathbf{2 0 0 8}$ & 4 & 25 & 18 \\
\hline $\mathbf{2 0 0 9}$ & 6 & 29 & 21 \\
\hline $\mathbf{2 0 1 0}$ & 4 & 17 & 32 \\
\hline $\mathbf{2 0 1 1}$ & 6 & 36 & 40 \\
\hline $\mathbf{2 0 1 2}$ & 8 & 41 & 49 \\
\hline $\mathbf{2 0 1 3}$ & 4 & 45 & 45 \\
\hline $\mathbf{2 0 1 4}$ & 8 & 48 & 46 \\
\hline $\mathbf{2 0 1 5}$ & 11 & 39 & 51 \\
\hline $\mathbf{2 0 1 6}$ & 3 & 38 & 63 \\
\hline $\mathbf{2 0 1 7}$ & 9 & 37 & 67 \\
\hline Cəmi & $\mathbf{7 0}$ & $\mathbf{4 0 4}$ & $\mathbf{4 7 0}$ \\
\hline
\end{tabular}

D) Müalliflarin aməkdaşlıq daracasinin müayyan edilməsi

Oməkdaşlıq dərəcəsinin (Degree of collaboration, DC) hesablanması (1) düsturu əsasında aparılır.

$$
D C=\frac{\mathrm{a}}{\mathrm{a}+\mathrm{b}}
$$

Burada a - çoxmüəllifli məqalələrin sayını, b - təkmüəllifli məqalələrin sayını bildirir. Oməkdaşlıq dərəcəsinin hesablanmasından məlum olmuşdur ki, jurnalda 1569 sayda çoxmüəllifli məqalə var. Onda IEEE TIFS jurnalının (1) düsturuna əsasən əməkdaşlıq dərəcəsi $1569 / 1639=0,96$ bərabərdir.

\section{E) Mahsuldar müallifin seçilməsi}

Codvəl 4-də bu jurnalda 2006-2017-ci illər ərzində ən çox məqaləsi çap olunan on müəllifin siyahısı verilmişdir.

CəDVӘL 4. MəHSULDAR MÜəLLIFLəRIN SIYAHISI

\begin{tabular}{|l|l|c|}
\hline № & \multicolumn{1}{|c|}{ Müəllifin adı } & Məqalə sayı \\
\hline 1. & JAIN A.K. & 28 \\
\hline 2. & HUANG J.W. & 26 \\
\hline 3. & SUSILO W. & 25 \\
\hline 4. & FRIDRICH J. & 24 \\
\hline
\end{tabular}

\begin{tabular}{|l|l|l|}
\hline 5. & LIU KJR & 21 \\
\hline 6. & MOULIN P. & 17 \\
\hline 7. & WU M. & 16 \\
\hline 8. & BARNI M. & 15 \\
\hline 9. & MU Y. & 15 \\
\hline 10. & PEREZ-GONZALEZ F. & 14 \\
\hline
\end{tabular}

\section{F) Maqalalarin təşkilatlar üzro paylanması}

2006-2017-ci illər ərzində çap olunmuş 1639 məqalənin təşkilatlar üzrə paylanmasına nəzər saldıqda 71 məqalənin Çin Elmlər Akademiyası, 59 məqalənin Nanyang Texnoloji Universitetinin payına düşdüyü aşkarlanmıșdır və cədvəl 5-də göstərilmişdir.

CəDVӘL 5. MəQALəLəRIN TəŞKILATLAR ÜZRə PAYLANMASI

\begin{tabular}{|c|l|c|}
\hline \multicolumn{1}{|c|}{ Təşkilatın adı } & $\begin{array}{c}\text { Məqalə } \\
\text { sayı }\end{array}$ \\
\hline 1. & $\begin{array}{l}\text { Çin Elmlər Akademiyası } \\
\text { (Chinese Academy of Sciences) }\end{array}$ & 71 \\
\hline 2. & $\begin{array}{l}\text { Nanyang Texnoloji Universiteti } \\
\text { (Nanyang Technological University) }\end{array}$ & 59 \\
\hline 3. & $\begin{array}{l}\text { Sinqapur Milli Təhsil İnstitutu } \\
\text { (National Institute of Education Singapore) }\end{array}$ & 59 \\
\hline 4. & $\begin{array}{l}\text { Maryland Universitet Sistemi } \\
\text { (University System of Maryland) }\end{array}$ & 52 \\
\hline 5. & $\begin{array}{l}\text { Kaliforniya Universiteti } \\
\text { (University of California System) }\end{array}$ & 51 \\
\hline 6. & $\begin{array}{l}\text { Nyu-York Suny System Dövlət Universiteti } \\
\text { (State University of New York Suny System) }\end{array}$ & 38 \\
\hline 7. & $\begin{array}{l}\text { Maryland College Park Universiteti } \\
\text { (University of Maryland College Park) }\end{array}$ & 33 \\
\hline 8. & $\begin{array}{l}\text { Miçiqan Dövlət Universiteti } \\
\text { (Michigan State University) }\end{array}$ & 32 \\
\hline 9. & $\begin{array}{l}\text { Vollonqonq Universiteti } \\
\text { (University of Wollongong) }\end{array}$ & $\begin{array}{l}\text { Milli Elmi-Tədqiqat Mərkəzi } \\
\text { (Centre National de la Recherche Scientifique) }\end{array}$ \\
\hline 10. & \\
\hline
\end{tabular}

G) Maqaləlarin ölkələr üzrə paylanması

Cədvəl 6-dan göründüyü kimi bu jurnalda çap olunan məqalələrin ölkələr üzrə paylanmasına görə də ABŞ və Çin ilk siralardadir.

CəDVӘL 6. MəQALəLӘRIN ÖLKəLӘR ÜZRӘ PAYLANMASI

\begin{tabular}{|c|l|c|}
\hline \multicolumn{1}{|c|}{ oo } & \multicolumn{1}{|c|}{ Ölkənin adı } & Məqalə sayı \\
\hline 1. & ABŞ & 677 \\
\hline 2. & Çin & 450 \\
\hline 3. & Avstraliya & 119 \\
\hline 4. & Sinqapur & 106 \\
\hline 5. & İngiltərə & 102 \\
\hline 6. & İtaliya & 101 \\
\hline 7. & Fransa & 70 \\
\hline 8. & Tayvan & 65 \\
\hline 9. & Kanada & 64 \\
\hline 10. & Cənubi Koreya & 60 \\
\hline
\end{tabular}

2. İstinad üzrə analiz: 


\section{“Informasiya tohlükosizliyinin aktual multidissiplinar elmi-praktiki problemlori” IV respublika konfransı, 14 dekabr 2018-ci il}

\section{A) Istinadların illor üzro paylanması, illor üzrə istinadın orta sayl}

Məlum olmuşdur ki, istinadların sayı hər il artır. Cədvəl 7dən göründüyü kimi əgər 2006-c1 ildə məqalələrə 16 dəfə istinad olunmuşdursa, 2017-ci ildə bu göstərici 8396-ya bərabər olmuşdur.

Cədvəl 7-dən göründüyü kimi ən çox məqalə və istinad 2014-2017-ci illəri əhatə edir.

CəDVəL7. ISTINADLARIN ILLəR ÜZRə PAYLANMASI

\begin{tabular}{|c|c|c|c|c|c|}
\hline İl & $\begin{array}{c}\text { Məqalə } \\
\text { sayı }\end{array}$ & $\begin{array}{c}\text { İstinad } \\
\text { sayı }\end{array}$ & $\begin{array}{l}\text { İstinadın } \\
\text { orta sayı }\end{array}$ & $\begin{array}{c}\text { Cəmi } \\
\text { (məqalə } \\
\text { sayı) }\end{array}$ & $\begin{array}{c}\text { Comi } \\
\text { (istinad } \\
\text { sayı) }\end{array}$ \\
\hline 2006 & 46 & 16 & 0.34 & \multirow{4}{*}{263} & \multirow{4}{*}{1399} \\
\hline 2007 & 70 & 165 & 2.36 & & \\
\hline 2008 & 70 & 447 & 6.39 & & \\
\hline 2009 & 83 & 771 & 9.29 & & \\
\hline 2010 & 85 & 855 & 10.1 & \multirow{4}{*}{544} & \multirow{4}{*}{6102} \\
\hline 2011 & 121 & 976 & 8.07 & & \\
\hline 2012 & 160 & 1582 & 9.89 & & \\
\hline 2013 & 178 & 2689 & 15.1 & & \\
\hline 2014 & 182 & 3895 & 21.4 & \multirow{4}{*}{826} & \multirow{4}{*}{24123} \\
\hline 2015 & 205 & 5204 & 25.4 & & \\
\hline 2016 & 216 & 6628 & 30.7 & & \\
\hline 2017 & 223 & 8396 & 37.6 & & \\
\hline
\end{tabular}

B) Istinad olunan sənədin növünün və sayının müəyyən olunmast

Məlumdur ki, istinadlar müxtəlif növ sənədlərdən (məqalə, tezis, kitab və s.) edilə bilər. Ona görə də ən çox istinad olunan sənədin növünün və sayının tapılmasının da mühüm əhəmiyyəti vardır. Cədvəl 8-də ən çox istinad olunan 5 məqalə göstərilmişdir.

CəDVӘL 8. əN ÇOX ISTINAD OLUNAN MəQALəLəR

\begin{tabular}{|l|l|l|c|}
\hline & Müəllifin adı & \multicolumn{1}{|c|}{ Məqalənin adı } & $\begin{array}{c}\text { İstinad } \\
\text { sayı }\end{array}$ \\
\hline 1. & $\begin{array}{l}\text { Li Jian; } \\
\text { Li Xiaolong; } \\
\text { Yang Bin; et al. }\end{array}$ & $\begin{array}{l}\text { Segmentation-Based Image Copy- } \\
\text { Move Forgery Detection Scheme } \\
\text { 2015, vol. 10, iss. 3, p. 507-518 }\end{array}$ & 438 \\
\hline 2. & $\begin{array}{l}\text { Pevny Tomas; } \\
\text { Bas Patrick; } \\
\text { Fridrich Jessica }\end{array}$ & $\begin{array}{l}\text { Steganalysis by Subtractive Pixel } \\
\text { Adjacency Matrix } \\
\text { 2010, vol. 5, iss. 2, p.215-224 }\end{array}$ & 326 \\
\hline 3. & $\begin{array}{l}\text { Chen Mo; } \\
\text { Fridrich Jessica; } \\
\text { Goljan } \\
\text { Miroslav; et al. }\end{array}$ & $\begin{array}{l}\text { Determining image origin and } \\
\text { integrity using sensor noise } \\
\text { 2008, vol. 3, iss. 1, p.74-90 }\end{array}$ & 298 \\
\hline 4. & $\begin{array}{l}\text { Kodovsky Jan; } \\
\text { Fridrich Jessica; } \\
\text { Holub Vojtech }\end{array}$ & $\begin{array}{l}\text { Ensemble Classifiers for } \\
\text { Steganalysis of Digital Media } \\
\text { 2012, vol. 7, iss. 2, p.432-444. }\end{array}$ & 290 \\
\hline 5. & $\begin{array}{l}\text { Fridrich Jessica; } \\
\text { Kodovsky Jan }\end{array}$ & $\begin{array}{l}\text { Rich Models for Steganalysis of } \\
\text { Digital Images } \\
\text { 2012, vol. 7, iss. 3, p868-882. }\end{array}$ & 278 \\
\hline
\end{tabular}

\section{NӘTİCə}

Məqalədə IEEE TIFS jurnalının 2006-2017-ci illər ərzində çap olunmuş buraxılışları analiz olunmuşdur. Analiz nəticəsində nəşr olunan məqalələrin və istinadların sayının hər il artdığı aşkarlanmışdır. Məqalələrin və istinadların sayının artması jurnalın IF göstəricisinin artmasına səbəb olmuşdur. Eləcə də, jurnalda çap olunan məqalələr arasında çoxmüəllifli məqalələr təkmüəllifli məqalələrdən üstünlük təşkil edir və jurnalda icmal məqalələrə çox az rast gəlinir. Burada diqqəti çəkən digər məsələ nəşrlərin ölkələr üzrə paylanmasında Sinqapur və Tayvan kimi ölkələrin G7 ölkələri sırasına daxil olmasinı qeyd etmək olar.

[1] R.Đliquliyev, N.İsmayılova, Bibliometria: müasir vəziyyəti, problemləri və inkişaf perspektivləri. Ekspress-informasiya. Bakı, 2015, $78 \mathrm{~s}$.

[2] A.Pritchard, Statistical bibliography or bibliometrics? Journal of Documentation, 1969; 25(4): 348-349.

[3] R.Alıquliyev, N.Adıgözəlova, "İnformasiya təhlükəsizliyi üzrə aparılan tədqiqatların bibliometrik analizi (2007-2016-c1 illər)". İnformasiya təhlükəsizliyinin aktual problemləri III respublika elmi-praktiki seminar1, 2017, s.56-58.

[4] N.Ismayilova, "Biblometric analysis of information security", İnformasiya təhlükəsizliyinin multidissiplinar problemləri üzrə II respublika elmi-praktiki konfransının materialları, 2015, pp. 106-109.

[5] C.Lu, W.Jen, W.Chang, "Trends in computer crime and cybercrime research during the period 1974-2006: A bibliometric approach", Proceed. of Pacific Asia Workshop on Intelligence and Security Informatics (PAISI 2007), 2007; 244-250.

[6] www.webofknowledge.com

[7] A.Dhiman, Ethnobotany journal: a ten year bibliometric study. IASLIC Bulletin. 2000; 45(4):177-82.

[8] S.K.Patra, P.Bhattacharya, N.Verma, Bibliometric study of literature on bibliometrics. DESIDOC Journal of Library and Information Technology. 2006; 26(1):27-32.

[9] M.W.Neff, E.A.Corley, 35 years and 160,000 articles: a bibliometric exploration of the evolution of ecology. Scientometrics. 2009; 80(3): 657-82.

[10] S. Thanuskodi, Bibliometric analysis of the journal Library Philosophy and Practice from 2005-2009. Library Philosophy and Practice (e-journal). 2010; 1-7.

[11] L.Bornmann, R.Mutz, Growth rates of modern science: a bibliometric analysis based on the number of publications and cited references. Journal of the Association for Information Science and Technology. 2015; 66(11): 2215-22.

[12] A.Abdi, N.Idris, R.Alguliyev, R.Aliguliyev, Bibliometric Analysis of IP\&M Journal (1980-2015). Journal of Scientometric Research. 2018; 7(1): 54-62

\section{BIBLIOMETRIC ANALYSIS OF THE JOURNAL "IEEE TRANSACTIONS ON I FORENSICS AND NFORMATION SECURITY" (2006-2017)}

Narmin Adigozalova

Institute of Information Technology of ANAS, Baku, Azerbaijan narmin66@gmail.com

Abstract - The paper performs bibliometric analysis of the articles published in years 2006-2017 in the journal IEEE Transactions on Information Forensics and Security (IEEE TIFS) indexed in Web of Science (WoS) database. The analysis is performed on the distribution of the articles and references by years, authors, organizations and countries.

Keywords: WoS, impact factor, reference, bibliometrics, bibliometric analysis. 